\title{
The European Union and Latin America
}

On June 10-11, 2015, the European Union (EU) hosted the second EU-Community of Latin American and Caribbean States (CELAC) Summit in Brussels. During the meeting, the Heads of State and Government of the nations of Latin America and the Caribbean participated in a comprehensive dialogue with the EU aimed at "working for prosperous, cohesive and sustainable societies for their citizens." This summit was the latest example of the EU's long-term interest in, and maintenance of, its political and economic relations with the Latin America and Caribbean (LAC) region.

\section{Background}

The European Union's interest in developing closer relations with the LAC region was formalized in 1990, when the EU held its first summit with the Rio Group (the Rio Group was founded in 1986 by six Latin America countries and later expanded to 23). The Rio Group became the official forum for the political dialogue between the EU and Latin America. The EU and Rio Group members met approximately every two years at the ministerial level and addressed issues of common interest ranging from human rights to poverty reduction, security, and the narcotics trade. In 1999, in an effort to elevate the importance of EU-LAC relations, the EU-Latin America and Caribbean Summit process was created. These summits, which met in the years between the EU-Rio Group ministerial meetings, brought together the highest-ranking EU officials and the Heads of State and Government of the LAC region. They introduced additional topics to the dialogue, including climate change, economic and financial issues, research and innovation developments, and energy.

In 2010, the Community of Latin American and Caribbean States (CELAC) was launched as a new mechanism for LAC regional political dialogue, replacing the Rio Group and incorporating 33 countries of the LAC. Significantly, the CELAC does not include the United States or Canada, both of which interact with the nations of the LAC in the Organization of American States. CELAC replaced the Rio Group and the EU-LAC Summit process as the new framework for EU-LAC dialogue. The first EU-CELAC Summit was held in 2013 in Santiago, Chile.

In addition to the CELAC, the EU maintains separate regional dialogues with the countries of Mercosur (Argentina, Brazil, Paraguay, Uruguay, and Venezuela); the Andean Community (Bolivia, Ecuador, Colombia, and Peru); Central America; the non-EU-linked Caribbean; and Mexico.

\author{
EU-Latin America and the Caribbean \\ * EU: 28 member states; CELAC: 33 member states \\ * Population of both EU and CELAC member states: I billion \\ * European Union GDP (2014): approx. €I3.9 trillion \\ * CELAC countries GDP (20I3): approx. \$8 trillion \\ * EU is the second largest trading partner for the CELAC region \\ (20I3), tied with China and behind the United States. CELAC is \\ the fifth largest partner for the EU. \\ * Trade in goods between EU and LAC is approximately $€ 209$ \\ billion (20I4). Trade in services is approximately $€ 72$ billion \\ (2013). \\ * EU is a leading foreign direct investor (FDI) in the CELAC \\ region amounting to approximately $€ 505$ billion (20I3), larger \\ than EU FDI in Russia, China, and India combined. \\ * CELAC region FDI in EU is approximately $€ I 35$ billion, with \\ Brazil and Mexico leading the way.
}

Source: United Nations, European External Action Service (EEAS), Eurostat. Exchange: $€ \mathrm{I}=\$ \mathrm{I} . \mathrm{I}$

\section{Political Dimension}

The second EU-CELAC summit was held in Brussels in June 2015 and was co-chaired by Donald Tusk, President of the European Council, and Rafael Correa, President of Ecuador, who holds the rotating presidency of the CELAC. Most of the 61 Heads of State and Government of the EU and LAC attended the summit. In addition to Tusk, JeanClaude Juncker, President of the European Commission, Federica Mogherini, the High Representative of the Union for Foreign Affairs and Security Policy, and Martin Schulz, President of the European Parliament, also represented the European Union.

The two-day summit concluded with a commitment by both sides to set a five-year agenda that would focus on reducing poverty; addressing climate change; and promoting education, science, and technology. The leaders also discussed issues such as relations with Cuba, the peace process in Colombia - during which the EU announced the creation of a fund to support post-conflict initiatives - and how to address the political instability in Venezuela.

Although the EU-CELAC summits represent a highly visible acknowledgement of the relationship between the $\mathrm{EU}$ and the LAC region, it is only one example of EUCELAC engagement. In the first half of 2015, High Representative Mogherini visited the LAC region on several occasions: attending the CELAC summit in January in Costa Rica, visiting Cuba, and attending the Summit of the Americas. Additional dialogues between the EU and CELAC region take place in the form of the EU-LAC Trade Union conference, the EU-CELAC organized civil society 
forum, CELAC-EU youth days, the EU-CELAC academic summit, and the EU-CELAC Business summit that was also held in June. The EU-LAC Foundation was also created in 2010 to promote a nongovernmental economic and sociocultural partnership between the two regions that would promote mutual understanding and common values between the EU and LAC. Headquartered in Hamburg, Germany, the foundation's current president is Benita FerreroWaldner of Austria, and the Executive Director is Jorge Luis Carrillo of Peru.

\section{Trade and Development Dimension}

The EU is one of the top three trading partners of the CELAC and one of the largest providers of development assistance to the LAC region. In addition to the overall volume of trade between the $\mathrm{EU}$ and the LAC region, the EU also relies on modest levels of oil and liquefied natural gas imports from the LAC region.

The EU is economically linked to the LAC region through a series of Association Agreements (Chile), Free Trade Agreements (FTA) (Colombia, Peru, Mexico) and an Economic Partnership (Caribbean). Negotiations with Ecuador and Cuba continue, as do the negotiations for an FTA with the Mercosur countries, which represent the fourth-largest non-EU economy in the world. At the 2015 EU-CELAC summit, both the EU and the Mercosur leaders pledged to intensify their negotiations in an effort to conclude a new FTA.

The EU's development assistance initiatives for Latin America are designed to address issues such as the reduction of poverty, sustainable growth, rule of law and security, among others, and have received an allocation of approximately $€ 925$ million for the 2014-2020 time frame.

The European Investment Bank has also allocated $€ 2.3$ billion for Latin America for the period 2014-20120 to support EU initiatives in the development of social and economic infrastructure, climate change mitigation, and private sector development.

\section{Parliamentary Dimension}

The EU's relationship with Latin America also includes an important parliamentary dimension. In 2006, the Euro-Latin American Parliamentary Assembly (EuroLat) was established. EuroLat consists of 150 members, 75 from the European Parliament and 75 from various Latin American groups, including the Andean, Central American, and Mercosur parliaments. Parliamentarians from Mexico and Chile are also included. Two co-presidents, currently Ramon Jauregu Atondo (Spain) and Roberto Requiao (Brazil), lead the assembly. Fourteen vice presidents (seven from each region) also make up the Executive Bureau. There are four standing committees that consider issues of mutual interest to the two regions and help develop recommendations and resolutions that could be submitted to the various ministerial groups for action as well as to the EU-CELAC summit.

\section{Going Forward}

Although there has been a long historical interest and relationship between Latin America, the Caribbean, and parts of Europe - driven mainly by Spain and Portugal but also the United Kingdom, the Netherlands, and Francerelations between the EU and Latin America are a fairly recent development. Launched in 1999, the political dialogue between the EU and the LAC region has been referred to, more regularly perhaps by the $\mathrm{EU}$, as a strategic partnership. Indeed, the relationship has resulted in a highlevel dialogue on a broad range of issues of mutual interest. It has also resulted in a number of sector-specific initiatives, negotiations on association agreements, and increased trade. Nevertheless, some observers might note that mention of the EU in conversations between Latin Americans and their U.S. counterparts rarely takes place. In fact, Latin American analysts may rarely see the EU mentioned even in Latin America itself. This observation, even if only half true, points to a serious potential flaw in the EU's efforts to maintain a strong presence and influence in the LAC region, despite the many high-level visits.

This point has also been noted by a few observers of EULAC relations. In addition to the fact that the United States remains the major political, economic, and trade influence in the LAC region, the inability of the EU to complete its trade agenda in parts of the region, and now the emergence of China as a major competitor of the EU in the LAC, has been a cause for concern in Brussels. China, with a huge market for the commodities and resources Latin America can export, and billions of dollars to invest (a proposed $€ 250$ billion), clearly has become a challenge to the EU's position in Latin America.

In a "Briefing" recently prepared by the European Parliament Research Service, this point was noted. The report observed that despite some positive developments in EU-LAC relations, the lingering impact of the global economic crisis, the emergence of China in the LAC space, the attractiveness of the dynamic Asia-Pacific region, and even EU member states more interested in events along Europe's eastern and southern borders, present major challenges ahead for EU-LAC relations.

For some in the EU, the 2015 EU-CELAC Summit could not have come at a better time. Although Europe's attention has recently been focused on the Greek financial crisis and the political instability in Ukraine, the summit offered an opportunity, in a highly visible way, for the EU to reaffirm relations with the leadership of the LAC states, restate the EU's interest in maintaining a presence in the LAC, despite the rise of China, and re-energize the EU's long-range policy goals and commitments in Latin America.

Vincent L. Morelli, vmorelli@crs.loc.gov, 7-8051 